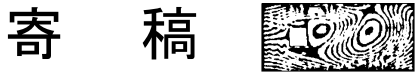

\section{名誉会員のご指名を頂いて \\ Nomination to an Honorary Member of JAWE}

\author{
田中 宏* \\ Hiroshi TANAKA
}

この度は日本風工学会から名誉会員のご指名を頂き, 驚かされましたが, 大変に名誉なことと存じます。ご 配慮下さった会員・幹事の方々のご好意に, 心より厚 く御礼申し上げます。

風工学とのお付き合いはもう 40 年以上になります。 橋梁工学を専攻する大学院学生として平井敦・伊藤学 両先生にご指導頂き, 宮田利雄先生, 久保喜延先生な どの優れた先輩・同僚と将来の本四連絡橋を夢見なが ら風洞実験室で屯して居たのが始まりでした。そのう ち PDF 研究員としてカナダの西オンタリオ大学に留 学する機会があり, ボスのアラン・ダヴェンポート教 授の指導のもと, 比較的年齢層の薄い若い研究者たち と共に, 新しい環境と強い刺激の中で様々な風工学プ ロジェクトに参加する体験を積みました。7 年間に亘 る境界層風洞実験室での毎日は日々に目覚めて行くよ うな経験でした。

1979 年からはカナダのオタワ大学で教鞭をとる一 方で, 研究費を獲得する為の仕事として構造物の対風 挙動などに興味を持っていました。近くに連邦政府の 研究機関である NRCC があり, 特に空気力学と構造 の両分野にはボブ・ワードロウ氏を始めとする優れた 研究陣があり, 橋梁に限らず風がテーマとして入って くる問題ではよく協力させてもらいました。1990 年に なって, デンマーク海事研究所から依頼されてストア ベルト吊橋の耐風問題に関するコンサルタントを勤め る機会があり，エリク・ヒヨルドハンセン，ニルス・ ギムシンク両教授やアラン・ラーセン氏をはじめとす る北欧の優れた研究者達と知り合い, 貴重な勉強をし
ました。更にその頃，仕事を通じて知り合ったウィー ンの技術者, ヘルムト・ヴェンツェル氏と, 風の問題 を含む構造動力学の問題に協力して仕事をすることに なり，それは極く最近まで続いて居りました。

私の仕事はこのように 40 年来, 殆ど国外でしたが, 実は日本風工学会の前身である風工学研究会が発足し た頃以来の「海外在住」メンバーとして, 多くの会員 諸氏から友人として扱って頂き, 有難く存じて居りま す。日本風工学会はその歴史を通じて, この分野では 世界で最も先進的な組織であり,この組織に認識され ることは私にとってかけがえの無い名誉であります。

会員諸氏のご好意に重ねて御礼申し上げます。今後 ともどうぞ宜しくお願い申し上げます。

* オタワ大学 名誉教授

Professor Emeritus, University of Ottawa 